\title{
Extending Urban Development on Water: Jakarta Case Study
}

\author{
Rukuh Setiadi \\ (Principal/Correspondent Author) \\ Department of Urban and Regional Planning \\ Diponegoro University \\ Tembalang Campus, Semarang \\ Indonesia 50275 \\ Email: rukuh.setiadi@pwk.undip.ac.id
}

\author{
Joerg Baumeister \\ School of Engineering and Built Environment - Architecture and Design \\ Griffith University \\ Gold Coast Campus, Southport \\ Australia 4215 \\ Email: j.baumeister@griffith.edu.au
}

Paul Burton

Cities Research Institute

Griffith University

Australia 4215

Email: p.burton@griffith.edu.au

\author{
Johanna Nalau \\ School of Environment - Urban and Environmental Planning \\ Griffith University \\ Gold Coast Campus, Southport \\ Australia 4215 \\ Email: j.nalau@griffith.edu.au \\ Daniel Ware \\ Griffith Center for Coastal Management \\ Griffith University \\ Gold Coast Campus, Southport \\ Australia 4215 \\ Email: d.ware@griffith.edu.au

\section{Elnaz Torabi} \\ School of Environment - Urban and Environmental Planning \\ Griffith University \\ Gold Coast Campus, Southport \\ Australia 4215 \\ Email: e.torabi@griffith.edu.au
}




\begin{abstract}
This paper introduces the concept of 'Sea Cities' which emphasizes the different ranges of tactics to acknowledge the relationship between the sea and cities. The concept is critical in opening opportunities and thoughts for integrating future aquatic-based urbanism to address climate change, particularly rising sea levels faced by the majority of coastal cities. We assess four sea cities tactics (i.e. fortify, accommodate, release, and floating) with a case study of Jakarta, which is deemed one of the most vulnerable metropolitans to sea level rise due to its overpopulation, while the land is sinking rapidly due to massive urban development. In order to understand the prospects and pitfalls of each tactic for Jakarta, we analyse scholarly sound literatures, official government reports and documents as well as policy briefs released by governments at the national level. This study finds that massive hard-structural solutions is not only insufficient, but also irrelevant to solve Jakarta's problems in facing the challenges of climate change, especially rising sea level, while the combination of accommodating and floating tactics have never been considered as future planning options for Jakarta. The combination of these two tactics could enable more resilient and adaptive solutions for the future development trajectory of Jakarta, and in doing so also provide key lessons for other coastal cities especially in the developing countries.
\end{abstract}

Keywords: sea cities, aquatic-based urbanism, sea level rise, floating city, Jakarta.

\title{
1. Introduction
}

Coastal areas have experienced globally fast population growth due to their marine-based attractiveness as places to live, work and visit. Today, approximately $53 \%$ of global population are living in the coastal areas across over 4285 coastal cities and agglomerations across the world, and half of these people are concentrated in almost 270 large cities (1-5 million people) and 15 metropolitans over 10 million people (Barragán and Andrés, 2015). This trend will continue as recent World Urbanization Prospect (2018) projects that by 2050 approximately $70 \%$ of populations live in cities. The scale and speed of the urbanisation process on the coast generates changes in land use that have never been seen before, which in most cases also causes serious damage to dynamic but fragile coastal-marine ecosystems and leads to social conflicts (Barragán and Andrés, 2015).

In addition to these basic sustainability issues, sea level rise has become the most alarming aspect of anthropogenic climate change (Nicholls, 2011; Dahlem, 2019) that exacerbate development on the coast and has affected billions of people living in the coastal region significantly, particularly in Asian megacities (Neuman et al, 2015). IPCC (2013) estimates that there will be approximately 26 to $82 \mathrm{~cm}$ increase in the mean sea level rise by the end of this century. Rapid urbanization, particularly in the low-lying coastal cities, has increased not only population's vulnerability but also urban assets exposure to sea level rise. Hanson et al (2011) estimated that the total value of assets exposed to coastal floods in 136 major port cities in the world is about 3000 billion USD which is equal to $5 \%$ of global GDP in 2005, and is projected to increase more than 10 times by 2070 or $9 \%$ of projected global GDP in this period.

Culture and civilization of coastal cities is greatly challenged by this situation. Urban planning has a role in encouraging sustainable adaptation in the face of rising sea level with some conditions that do not seem easy (Hurlimann et al, 2014) as the concepts, methods and assumptions that urban planners have relied on in previous decades to protect people, ecosystems and physical structures are inadequate, unless they explicitly account for a 
rapidly changing regional climate context, specifically from a hydrological and ecological perspective (Hill, 2016). Recent study shows that most adaptation to sea level rise have taken a moderate pathway to address the issue through local comprehensive plans and hazard mitigation plans, but often face massive challenges in implementation (Fu et al, 2017).

Reise (2017) state that public debate on the future of coastal cities should not be postponed. No matter how advanced cities can build defence infrastructures and technologies to protect them from floods, they now have to think further as climate change and sea level rise may undermine its effectiveness in the long run. Mega (2019: 87) stated that 'the battle for climate change will be won or lost in cities and the seas'. A new way of thinking to understand the relationship between cities and oceans in the climate change era is essential. While cities are the largest theatres of human civilization in this century, oceans are the largest resource on this planet, which contains $97 \%$ of total water and $99 \%$ of all life forms on earth (UN-SDG, 2019). Drawing from Bruyns and Hasdel (2017), if we agree to place ocean not only as a threat and challenge but also as an urban resource, new questions emerge of the role of the sea in the future urbanity in how to address future humanity issues.

In this paper, we introduce the idea of 'Sea Cities' which particularly emphasises the different ranges of tactics to re-imagine the relationship between the sea and cities. We first review the concept of "sea cities" and which tactics have been proposed and seem relevant in particular for such coastal cities in a changed climate. We then explain the current strategies done in Jakarta, the capital city of Indonesia which is one of the most vulnerable metropolitan to sea level rise due to its overpopulation, while the land is sinking rapidly due to massive urban development and underground water exploitation in the coast. Our focus on Jakarta is significant given that Deltares (2015) placed Jakarta as the second fastest sinking cities after Tokyo, with mean cumulative subsidence is about 2 meters from 19002013 , with maximum rate $17.9 \mathrm{~cm}$ per year, and estimates an additional subsidence up to 1.8 meters until 2025. Recently, the national government has also announced a bold decision to shift the capital city from Jakarta to Kalimantan. We then provide a discussion and recommendations as to how these tactics can be implemented and what future scenarios for urban planning and development in a changed climate could look like for Jakarta.

\section{Sea Cities: A Review of Literature}

'Seas' and 'cities' are subjects of Sustainable Development Goals (SDGs), Goal 14 and 11 respectively. Both are ecologically, economically, and socio-politically interconnected to address barriers and seize opportunities for sustainable development. The term 'sea cities' is hardly found in the search of scholarly literature. Most scholarly literature associates sea cities as geographical locations (e.g. Baltic Sea cities, Black Sea cities, etc.) instead of as a specific concept. In this section we introduce the Sea Cities concept and explore how the idea could address the climate change challenge particularly to sea level rise on cities. However, introducing the term 'sea cities' is challenging as it requires explanation at least how it differs from other well-established concepts such as coastal, seaside, and waterfront cities. The complexity also arises whether floating cities concept is also part of sea cities or is maritime-based development entirely about sea cities. These interlinkages reflect that the relation of sea and cities could be translated, interpreted and perceived differently by researchers depending on one's disciplinary background.

\subsection{Definition and Related Concepts}

We define sea cities as a concept that views both sea and cities in a balanced manner in comparison to other terms. Sea Cities is a proposed framework in responding to this climate 
change challenge for cities in the coastal regions. Sea cities concept what do we mean is about transforming all city elements from terrestrial to aquatic based. These city elements include human settlement and building, economy or livelihoods, community, and infrastructure networks (CRI, 2019). We borrow the well known concept such as waterfront development, reclamation of artificial island, and other coastal physical infrastructure protection. However, we do not associate them or take them for granted as sea cities simply because these concepts to somehow remains terrestrial-based.

Most works on waterfront development can be found in architecture, urban design and planning disciplines. Waterfront cities have been highly perceived as concept to increase the economic value and the identity of a place, which is in seaside of the ocean, and serve as urban regeneration ideas (Samant and Brears, 2017; Buckman and Hamdan, 2016; Clemente, 2013). Therefore, through waterfront development we may see transformation part of city from traditional port and industrial activities with factories, warehouses and related infrastructure to a waterside living and commerce, which is strengthened by recreation, heritage, art, entertainment and tourism related uses. The shrinking urban spaces, densification due to urban migration to cities, and damaging urban sprawl to natural environment has become motivation behind the waterfront development. Additionally, there is also social justice motivation which is to giving back remarkable edge in between land and the sea to the public. Samant and Brears (2017: 332) conceptualize that 'waterfronts are contested territories whereby social and recreational needs of the local community are often overridden by real estate-driven and larger tourism-focused developments focusing primarily on economic gains'.

Matsumoto (1985) studied various types and characteristics of offshore man-made islands and explicitly call them as a sea city. Development of artificial islands involving land reclamation has been practiced for decades. However, reclamation of land eventually creates a new environmental problem and presents a limitation to continuously deal with sea level rise. Traditional settlements of Bajo Community in the eastern part of Indonesia where the foundation is built from dead coral, are not really sustainable not only from its changing fishing practice (Ali et al, 2019), but also in the face of high population growth and lack of waste management system. Modern land reclamation practice also brought similar environmental issues. Samant and Brears (2017) state although development of artificial island has increased $22 \%$ of Singapore land since 1960s, it has resulted in damages on oceanic environment and ecology. The damaging effect is even greater as the sand being sourced comes from Vietnam, Malaysia, Cambodia and Indonesia, and it causes devastating effects on coral reefs and sea-grass beds in the South China Sea and Indonesian water respectively. Ambitious and extensive of 12 billion USD reclamation project of Palm Island in Dubai (Salahuddin, 2006; Booth, 2008) also presented comparable case, along with on-going development of the World Replica Islands which consuming 320 million cubic of sand to make them.

Recent literature also highlights the increasing global trend of floating neighbourhoods and space on water (Bus et al, 2018; Clarck, 2016). Wang et al (2019) examine the feasibility of an innovative and sustainable concept for urban dwelling offshore by Modular Floating Structures (MFS) (Figure 1), which is based on small modular floating units consolidated into large scale useable surface for urban development. With respect to the proposed MFS concept, this study even delivers traditional engineering solutions for development of Very Large Floating Structures (VLFS). Wang et al (2019: 521) argue in further detail that:

'floating structures is one solution for sustainable expansion of coastal cities to their adjacent maritime environment, as an alternative to land reclamation ... Land scarce countries have adopted the concept of floating structures, mainly VLFS, as the most viable alternative to the land reclamation method... However, despite its popularity in literature, actual implementation of VLFS is limited due to its manufacturing complexity and transportation constraints, together with policy issues and regulation.' 
Figure 1. Modular Floating Structure - A neighbourhood of 2280, each 140 meters square

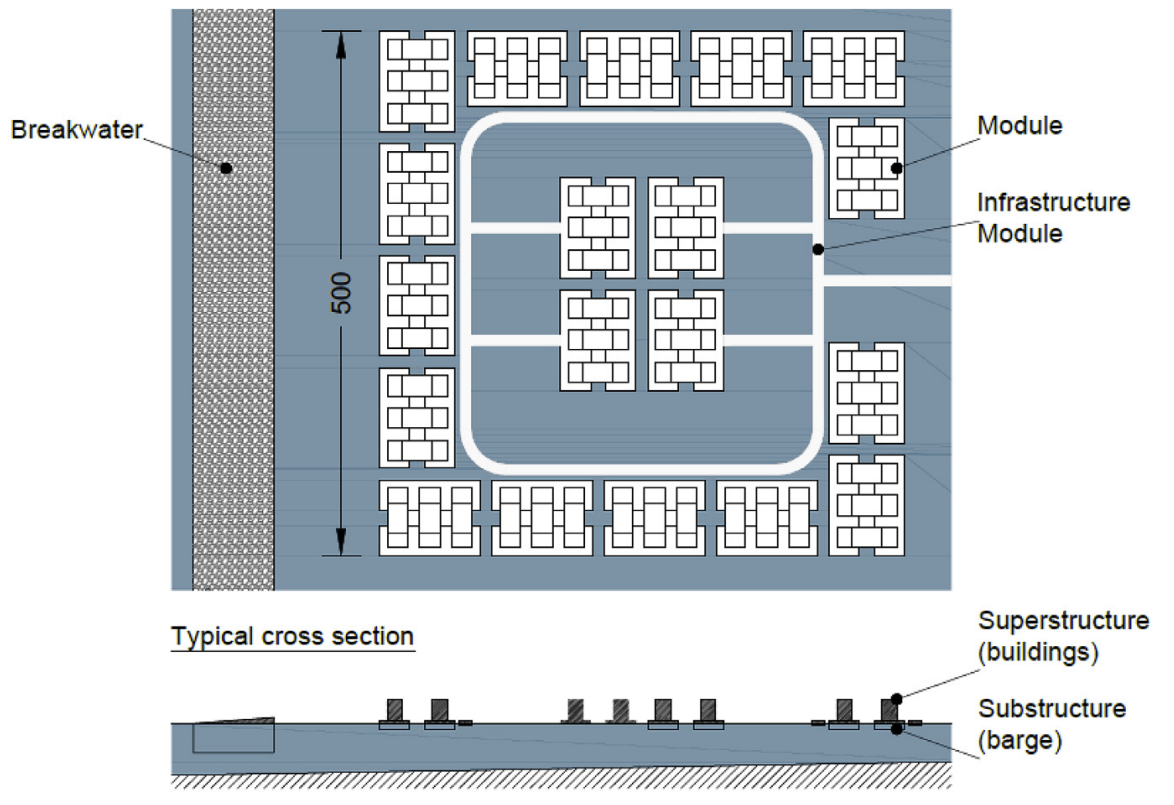

Source: Wang et al, 2019: 522

These recent literatures suggest an utopian model of modern floating cities. It translates ocean resource-based paradigm perspective into design which is perceived as responding to human needs, land scarcity while future forward-looking and respects the natural process including global environmental change such as sea level rise. The following quote illustrates one of versions of Sea Cities concept (Bryant-Tokokalau, 2018: p.37):

\begin{abstract}
'A city that floats on vast 'lily-pads' on the surface of the Pacific. The futurist design involved 'island(s) nearly two miles across, with a central tower rising half a mile to form a 'city in the sky'. The tower will house residential units for 30,000 people and space for offices, services and shops.' [lt] will be self-sufficient in food with the central shaft of the island being used to grow vegetables and fruit. The flat base of the island, which will be tethered to the ocean floor far below, will have a residential zone for another 10,000 inhabitants, along with forests, beaches and arable land, as well as port facilities. [Each] individual units can be connected to form floating 'cities' of up to 100,000 people.'
\end{abstract}

However, our ocean is underused and is free from exploitation is not really correct. North Sea, the smallest oceans, approximately at 570 thousand square kilometres, which is surrounded by a number UK and North European countries, for example, has been overused for shipping lane, underwater cable and pipe networks, marine fisheries, offshore mining, wave energy plants, and tourism of the neighbouring countries. Vress (2019) has proved the increasing use and demand of utilization North Sea in Netherland sector and sought for marine spatial planning. Integrated coastal zone management (ICZM) is a dominant approach to address emerging and potential conflicts from the increasing use of ocean and coastal areas. The approach focuses on how government can facilitate a transition from sectoral and segregated coastal development to sustainable coastal development via a participatory planning process integrating disciplinary knowledge, sectors and governance levels (Ware, 2017). Despite the usefulness of the ICZM to harmonize 
development interests in the coastal area, some studies show that the approach is not always successful leading to the displacement of coastal ecosystems and the intensification of development in the coast exposed to natural hazards (Ware, 2017).

\subsection{Sea Cities Tactics and Climate Change}

Environmental planning for cities will only become more urgent as we enter a new climate period (Hill, 2016). Meanwhile, Mariano and Marino (2018) suggest that in responding to climate change, city planners must re-think some structural limitations of urban shapes, which basically require a new perspective and deep contemplation to reorganize the configuration of cities and their water territories. Sea cities concept is about transforming all city elements from terrestrial to aquatic based. The transformation varies from the most reactive (e.g. provision of coastal infrastructure protection) to the moderate (e.g. living with water) and to the sophisticated (e.g. generating new urban shape), which depend on the characteristic of places, problems, and other underlying assumptions on vulnerability. These transformations could be seen from the range of selected Sea Cities strategies or tactics. We introduce four sea cities tactics: Fortifying, Accommodate, Release and Floating. The first three tactics are completely similar to strategies outlined in the IPCC (2013): protect, accommodate and retreat respectively. The IPCC (2013) distinguishes hard structure protection as advance strategy and soft structure protection as ecosystem-based adaptation. Unfortunately, at the time of the last IPCC assessment report, the literature seems to have been scarce on floating tactics.

Fortifying is a tactic in responding to sea level rise through strengthening existing flood protection and sea defence infrastructure system for cities. It ranges from the development of revetment, dyke, wave breaker, tide gate, to massive giant seawalls. It also includes technological application to brace natural processes so that the existing system of cities can be protected, such as through the beach nourishment, dune restoration, and mangrove conservation. Shannon (2018) states that although hard-structural interventions appear to be straightforward response to flooding and rising sea level, it is questionable for its effectiveness in the long run and its unintended negative externality by transferring the floods to surrounding coastline towns and cities.

Accommodate is another tactic in responding to sea level rise through substantial adjustment of physical and socio-economical system of cities. The idea is to familiarize all decision makers, related stakeholders and particularly affected people with a new fact and value that they need to 'living with water'. It means these agents should acknowledge that the transformation of development practices in responding to water excess from ocean at the city from various physical, social, and economical aspects needs to occur. Some examples of this tactic include elevated housing and infrastructure and development of new building codes. Shannon (2018:8-9) argues that 'one of the drawbacks associated with softening landscape and accommodating water often leads to designating a majority of lowlying area for landscape, resulting in straying away from architectural development in these areas.'

Release is one of sea cities tactics which is built on an assumption that cities are no longer able to accommodate the pressure of sea level rise. Efforts either to protect or make adjustment may higher than give it up to the sea. In other words, cities sacrifice to relocate their physical, socio and economical system to other higher places inland away from the sea. Though this tactic seems obvious, several negative consequences follows, such as crowding and encroachment of inland regions, as well as abandonment of viable architecture and infrastructure in the endangered locations that can take decades to rebuild (Shannon, 2018).

Floating is the last sea cities tactic which is somewhat atypical considering the possibility to bring all systems of a city from the terrestrial to the aquatic-based together. Some might see 
this tactic is too radical. Shannon (2018:12) for example mentions that floating structure 'may not react positively to fluctuating storm surges and increased wave momentum, which is becoming increasing characteristics of the predicted severity of coastal weather. The practicality of an individual being able to remain in a floating home throughout the duration of a storm surge may not be feasible as coastal storms get progressively worse due to climate change'. In fact, engineers and scientists are investigating and are quite close to addressing this issue by introducing modular assemblies, designed and tested computationally using advanced modelling techniques to grow and create formations in waterfront cities (e.g. Bus et al, 2018; Wang et al, 2019). Other supporting technologies has been envisaged such as wave technology, desalination, living wall, Titanium Dioxide, and solar panels (Frith, 2017).

There has been evidence that this alternative should not be underestimated. Boat house and floating neighbourhood housing units in the Netherlands are small scale and partial example of this tactic. Some large scale and comprehensive example of this tactic remains in the form of project plans, such as Venus Project in the USA and initiative of floating island on French Polynesia. However, one of the promising projects that illustrate this tactic is reported and known as Manta Ray project, a city inhabited by several thousand people that is completely movable efficiently on the ocean. It is also designed to be sustainable, zerocarbon and to run off renewable energy. Frith (2017) illustrate the project as follows:

'The shape of the vessel is of a manta ray. It is designed to be roughly $3,000 \mathrm{ft}$ long and $1,500 \mathrm{ft}$ wide. It will hold up to 7,000 people.... This shape took inspiration form the manta ray, because of how effortlessly it glides throughout the water with no resistance. It will rise up 200 feet above the ocean's surface and 400 feet below the ocean's surface. There is a lagoon in the middle of the ship that will host sea vessels and little bays where researchers can use them for research and observation of marine wildlife.... likely it will be using some wave energy technology. As of right now it is predicted to be completed by 2050.'

These tactics are not independent each other and difficult to weight on which one is the best as the characteristic of places, problem and underlying assumptions of vulnerability are not the same. Dahlem (2019) reveals that sea level rise policy option of local governments has a relationship to three dimensions of ocean-space, namely: how local physical reality of ocean is perceived, how ocean resources are utilized locally, and how ocean are conceptualized. It is also important to consider the combination of two or more tactics, as Nicholls (2011:144) suggests that combination of strategies (i.e. protect, accommodate, and retreat) is important to adaptation to sea level rise and should 'consistent with responses to all coastal hazards as well as with wider societal and development objectives'. From disaster risk point of view, Adnan and Kreibich (2016) also suggest a comprehensive and mixed combination of hard infrastructure to protect cities and non-structural solutions to reduce the exposure to floods.

Adaptation planning to the impact of sea level rise is problematic because existing adaptation planning frameworks fail to specify the preferred coastal adaptation strategies for certain locations (Reiblich et al, 2017). They argue that there is no 'one size fits all' coastal adaptation strategy or set of strategies, so that suggest place-based coastal adaptation decision making.

Instead, the appropriate strategy for a specific location will depend on the unique characteristics of that location. In other words, coastal adaptation decision-making should proceed in a place-based way, with strategies chosen because they are tailored to that specific location. Some locations might require legal changes, such as changes to zoning ordinances. Other locations might prompt engineered solutions, such as built protective structures, but only those possible and preferable under existing legal limitations and certain characteristics of that property. Still other locations might prompt creative financial tools to help foster coastal adaptation, such as conservation easements. (Reiblich et al, 2017: 167) 
Gibbs (2019) also confirms this point of view, from contrasting perspectives. He stated that 'despite the similarity in the cities and towns considered in the analysis and the commonality of risk arising from sea level rise, no consistent set of adaptation recommendations arose that was common across the communities. This lack of consistency suggests a lack of understanding of the effectiveness and implementability of many of the proposed adaptation responses.' (p. 131). Next, we describe the methods underpinning this research before presenting results and the discussion.

\section{Methods}

This study employs a case study approach, and Jakarta is selected as case study example for a number of reasons. Firstly, the city has been experiencing continual pressure from various issues associated as metropolitan coastal cities, such as high population growth and land conversion to urban use massive for different urban interests leading to detrimental effect to the Jakarta's coast. Secondly, the city is subject to the impacts of climate change, particularly floods and sea level rise, while at the same time the land is sinking due to excessive underground water exploitation. Thirdly, Jakarta has done several programs and projects to address the issue of urban floods and sea level rise and it has been reported in scholarly literature.

In order to assess the sea cities tactics for Jakarta, we developed a set of criteria for assessment. We built assessment criteria based on place-based coastal adaptation decision making model (Reiblich et al, 2017) that encompasses a number of enabling and limiting factors (Table 1).

Table 1. Enabling and Limiting Factors of Coastal Adaptation Decision Making

\begin{tabular}{|l|l|l|}
\hline Aspect & Factors & Enabling and Limiting Factors/ Assessment Guidelines \\
\hline Technical & $\begin{array}{l}\text { Geomorphologic } \\
\text { features }\end{array}$ & $\begin{array}{l}\text { Does geomorphologic features of Jakarta coast suitable for } \\
\text { the implementation of these tactics? }\end{array}$ \\
\cline { 2 - 3 } & Current zoning & $\begin{array}{l}\text { Is current zoning in Jakarta aligned with the implementation } \\
\text { of these tactics? }\end{array}$ \\
\cline { 2 - 3 } & $\begin{array}{l}\text { Existing land uses } \\
\text { and densities }\end{array}$ & $\begin{array}{l}\text { Do existing land uses and population densities suitable for } \\
\text { the implementation of these tactics? }\end{array}$ \\
\hline Environment & Existing habitats & $\begin{array}{l}\text { Do existing habitats of non-human species under threat by } \\
\text { the implementation of these tactics? }\end{array}$ \\
\hline Culture & $\begin{array}{l}\text { Cultural attachment } \\
\text { and values }\end{array}$ & $\begin{array}{l}\text { Does implementation of these tactics suitable with cultural } \\
\text { attachment and values of Jakarta's people? }\end{array}$ \\
\hline Economy & 'Takings' issues & $\begin{array}{l}\text { Does implementation of these tactics result in 'taking' issues } \\
\text { (e.g. low appraisal land values, diminishing livelihoods? }\end{array}$ \\
\cline { 2 - 3 } & Cost & $\begin{array}{l}\text { Is the cost of implementation of these tactics justifiable from } \\
\text { government and private? }\end{array}$ \\
\hline Politics & Political will & $\begin{array}{l}\text { Do implementation of these tactics bring political advantages } \\
\text { for the government? }\end{array}$ \\
\cline { 2 - 3 } & $\begin{array}{l}\text { Jurisdictional } \\
\text { overlaps }\end{array}$ & $\begin{array}{l}\text { Are there any political boundaries or jurisdictional overlaps to } \\
\text { implement these tactics? }\end{array}$ \\
\hline
\end{tabular}

Source: Adapted from Reiblich et al (2017)

The aim of this study is to understand the underlying factors for each tactic in the case of Jakarta rather than aiming to select the most suitable tactic. As part of assessment at the strategic level using sea cities perspective, this study uses qualitative analysis of various data sources. In order to understand the prospects and pitfalls of each tactic for Jakarta, data and information was obtained from secondary sources, peer-reviewed scholarly literatures around the issue in Jakarta, official government reports and documents as well as 
policy briefs released by governments at the national level (e.g. Bappenas, President Staff Office, etc). At the end, we will elaborate this assessment to discuss further three basic questions: (i) Which tactics can enable Jakarta to develop sustainable strategies to reduce the impacts of flooding and future sea level rise? (ii) Which tactics open more opportunities for Jakarta? and (iii) What transitions are needed for Jakarta to take up these tactics.

\section{Jakarta Case Study}

\subsection{Highlighted Future Problems and Challenges}

Jakarta is the biggest port city in Indonesia and serves as the capital city. Jakarta's port, formerly known as Batavia, played an important role throughout 18th to early 20th century in satisfying the European demands of herbs, spices and timber. These commodities were shipped out from the ports of Jakarta by the Dutch back to Europe. The connection between the seaport and the city is inseparable. The port is one of the 'engines' explaining growth and development in Jakarta, as Pultrone (2014) mentions that territorial transformation of coastal cities has a historical root involving its relationship with the sea. Today, the port serves the majority of national and international import and export freight flows, with annual increase in goods flow of up to $23 \%$, it is projected that this growth will continue. The plan of port expansion is also underway with total investment almost USD 3.5 billion and is targeted to be complete by 2030 aligned with other urban development in the eastern section of the Jakarta Bay (Delphine et al, 2019).

Another important engine of growth is the population. In 1950, the population of Jakarta was less than 1.5 million people. The number quadrupled in 1980 causing rapid industrial and commercial development, increased population density and centralized population in coastal areas. Urban expansion of Jakarta also spread out continuously away from the coast. As there is no determined urban growth boundary, land use change and land clearing have been massive over the period. This urban growth has reached over to adjacent administrative cities (e.g. Bogor, Depok, Tangerang, and Bekasi) which combines them into a single metropolitan, a home of more than 30 million people.

The current population in Jakarta administrative city itself is about 10.6 million people (UNDESA, 2018). They live in 662 square kilometre of land area, with average density more than 16,000 people per square kilometres. Thirteen rivers flow through Jakarta with their upstream on its hinterland beyond administrative border. Lack of drainage and stormwater infrastructures have caused Jakarta to be prone to floods in rainy seasons. Flood with inundation coverage above $40 \%$ of the city occurred in 1996, 2002, 2007 and 2013. Urban development growth in Jakarta have led to high demand of water, approximately 294 million cubic metre of water in 2014 (Apip et al, 2015). While surface water is highly polluted and piped water does not cover all city areas, the use of underground water has been massive, leading to land subsidence reaching an average of $10-15 \mathrm{~cm} /$ year or more, particularly in North Jakarta. These circumstances in addition to climate change have placed Jakarta as one of the most vulnerable coastal cities in the world. Ward et al (2011) estimates Jakarta's loss from flood events with a return period of 100 years is about USD 4.4 billion and this number increases by a factor of 4-5 by 2100. Apip et al (2015:3) state 'subsidence causes the Jakarta sea defence to sink below critical levels and has a major impact on the quality of life in the city'.

\subsection{What has Jakarta Done?}

Octavianti and Charles (2018) state although land subsidence in Jakarta, which is also exacerbated by the impact of climate change especially sea level rise, has been found as an issue since 1990s and even before, it did not attract government and policymakers to consider seriously Jakarta's coastal areas until 2007, when the worst flood in the city's 
history occurred. According to the Indonesia National Planning Agency, the floods inundated about $60 \%$ of the city just in 24 hours, killed 79 people, displaced 500,000 more and caused almost USD 690 million in losses (Octavianti and Charles, 2018). The flood finally brought to attention the issue of flood management (Octavianti and Charles, 2018) through a study called Jakarta Coastal Defence Study (JCDS) commissioned by the Ministry of Public Works with significant involvement of the Netherland-based development agency and Dutch engineering firms. Another flood in 2013 has changed the government's response to the issue (Octavianti and Charles, 2018).

In the following October of 2014, the Government of Indonesia launched the Masterplan of the National Capital Integrated Coastal Development (NCICD), which is a joint project of the national government and the Netherlands through the JCDS's funding from the Dutch government. NCICD aims to solve Jakarta's flood and sinking problem trough the development of a giant seawall located 2.5 kilometres north of offshore Jakarta Coast, while achieving additional benefits such as: providing space for new housing and real estate projects, creating a freshwater water retention lake which could supply fresh water for Jakarta, reducing Jakarta's traffic issue through adding ring road on top of the seawall. Moreover, the seawall would provide a new icon for Jakarta, as the overall design of the project would be shaped like the Garuda, a mythical eagle of Indonesia's national symbol. The project is relatively massive as it would involve development of 32 kilometres, 1250 hectares land reclamation, and a 7500 hectares water retention basin (Van Dijk, 2016, Octavianti and Charles, 2018; Wade, 2019). Table 2 shows detailed components of the NCICD project.

Table 2. Project Components of the NCICD

\begin{tabular}{|c|c|}
\hline NCICD Masterplan & Corresponding Components \\
\hline Land subsidence control & $\begin{array}{l}\text { - } \text { Piped water supply } \\
\text { - Stopping underground water extraction } \\
\text { - Subsidence monitoring }\end{array}$ \\
\hline Sanitation projects & $\begin{array}{l}\text { - Provision of sewerage } \\
\text { - Sewerage treatment } \\
\text { - Promoting of sewerage system connection }\end{array}$ \\
\hline $\begin{array}{l}\text { Strengthen current sea wall } \\
\text { and river dykes }\end{array}$ & $\begin{array}{l}\text { - Existing sea wall and river dykes (Component A)+ } \\
\text { upgraded pump stations } \\
\text { - Outer dyke (Component B) + new pumping stations } \\
\text { - Outer dyke (Component C) }\end{array}$ \\
\hline Ring road & - Ring road \\
\hline Enlarging the port & - Enlarging the port \\
\hline Additional space for industries & - Reclamation of artificial island for industries \\
\hline $\begin{array}{l}\text { Additional housing and new } \\
\text { sea front }\end{array}$ & $\begin{array}{l}\text { - Reclamation of artificial island for housing and new } \\
\text { sea front }\end{array}$ \\
\hline $\begin{array}{l}\text { Environmental impact } \\
\text { assessment (EIA) }\end{array}$ & - Improve environment in river and coastal area \\
\hline
\end{tabular}

The project draws scepticism of many scholars' such as Van Dijk (2016) from financing and even more from policy and political economy perspectives, such as Octavianti and Charles (2018) who introduce the idea of 'disaster capitalism' and Wade's (2019) 'hyper-planning' process of NCIDC. It is intriguing because the project itself would cost about USD 50 billion, while the Indonesian government was reluctant to spend money on the project (Van Dijk, 2016). The government built a narrative that many other parts of Indonesia need more 
attention and it is possible for NCICD to implement the project through private financing. However, Van Dijk (2016) warned that the government still need to make initial investments to create conditions so that suitable public-private partnerships can be found and if appropriate financing mechanism for private sector involvement can be used, considering each project component brings different interest to private parties.

Despite the virtues portrayed by media to save Jakarta from sinking, the NCICD has been criticized mainly for its process which did not involve the most affected community in North Jakarta whose livelihoods are dominated on their relationship with the sea, such as fishermen, micro business (e.g. salted fish), traders, and other informal sectors in the coast. The process was also criticized for ignoring the ecosystem sustainability since the reclamation involve dumping 600 million cubic of sand to the Jakarta's coast. The project also resulted in environmental destruction in the surrounding Jakarta (e.g. Banten Province) where the sand is mined. However, the most significant critics, which then sparked massive movement to reject NCICD, was about the transparency of the project. The Save Jakarta Bay Coalition (2006) accused that private/ corporation interests override the project to save Jakarta through reclamation of 17 artificial islands in addition to corruption scandals and bribery, which was actually not part of NCICD (Octavianti and Charles, 2018). The Save Jakarta Bay Coalition (2006) reported that this bribery case is linked to forced evictions of coastal communities, which in 2015 alone there were 113 cases of forced evictions affecting 8,145 families and 6,283 micro businesses. Following the scandal, the project was politicized as it was timely with the election of Jakarta Governor in 2017 and the beginning of political contestation for presidential election in 2018 , which deviates from the topic of this paper.

In the mid 2018, the elected Jakarta Governor released governor regulation to stop the reclamation of 17 artificial islands, although it resulted dispute with the developers as they stand on Presidential Decree signed by President Soeharto back in 1995 regarding reclamation of Jakarta Coast for urban development. Finally, to mediate this dispute, President Widodo ordered six months comprehensive evaluation to the NCICD masterplan including the integration of reclamation of 17 artificial islands into the masterplan. It adds the total area reclamation of the NCICD to almost $8 \%$ of Jakarta territory. Octavianti and Charles (2018:396) state 'this integration was a painful addition to the seawall plan because, at times, the islands are more disputed than the NCICD'. While the evaluation suggested that the Indonesian government committed to complete Component A, the Jakarta Post (2019) recently reported that the second phase of NCICD had begun and added Korean partners in the project.

Other than $\mathrm{NCICD}$, in responding to the threat of floods, Jakarta has adopted several disaster risk policies which spread over different domains including environmental and natural resource management, planning regulation and management, and adaptive and preventive measures. All of these policies can be summarized in Table 3.

Table 3. Disaster Risks Related Policies Adopted by Jakarta

\begin{tabular}{|l|l|l|l|l|l|}
\hline Domain & Policies & Y/N & Aim & $\begin{array}{l}\text { Type of } \\
\text { Policy } \\
\text { Measures }\end{array}$ & $\begin{array}{l}\text { Area of } \\
\text { Implementation }\end{array}$ \\
\hline $\begin{array}{l}\text { Environmental } \\
\text { and natural } \\
\text { resource } \\
\text { management }\end{array}$ & $\begin{array}{l}\text { Wetland } \\
\text { protection and } \\
\text { improvement }\end{array}$ & $\mathrm{Y}$ & $\begin{array}{l}\text { Improve water } \\
\text { navigability and } \\
\text { water detention } \\
\text { area }\end{array}$ & $\begin{array}{l}\text { Restoration } \\
\text { existing } \\
\text { wetland }\end{array}$ & $\begin{array}{l}\text { River and other } \\
\text { water bodies }\end{array}$ \\
\hline
\end{tabular}




\begin{tabular}{|c|c|c|c|c|c|}
\hline Domain & Policies & $\mathrm{Y} / \mathrm{N}$ & Aim & $\begin{array}{l}\text { Type of } \\
\text { Policy } \\
\text { Measures }\end{array}$ & $\begin{array}{l}\text { Area of } \\
\text { Implementation }\end{array}$ \\
\hline & $\begin{array}{l}\text { Enhancing } \\
\text { green area }\end{array}$ & $\mathrm{Y}$ & $\begin{array}{l}\text { Improve } \\
\text { groundwater } \\
\text { recharge }\end{array}$ & Regreening & Floodplain \\
\hline & $\begin{array}{l}\text { Ecological storm } \\
\text { surge barrier }\end{array}$ & $\mathrm{N}$ & - & - & - \\
\hline \multirow[t]{3}{*}{$\begin{array}{l}\text { Planning } \\
\text { regulation and } \\
\text { management }\end{array}$} & Risk zoning & $\mathrm{Y}$ & $\begin{array}{l}\text { Reduce risk to the } \\
\text { vulnerable } \\
\text { settlements }\end{array}$ & $\begin{array}{l}\text { Locating } \\
\text { settlements } \\
\text { that are in } \\
\text { risk }\end{array}$ & Whole city \\
\hline & $\begin{array}{l}\text { Building code/ } \\
\text { regulation }\end{array}$ & $\mathrm{N}$ & - & - & - \\
\hline & $\begin{array}{l}\text { Development } \\
\text { control }\end{array}$ & $\mathrm{N}$ & - & - & - \\
\hline \multirow{4}{*}{$\begin{array}{l}\text { Adaptive and } \\
\text { preventive } \\
\text { measures }\end{array}$} & $\begin{array}{l}\text { Protection of } \\
\text { critical facility }\end{array}$ & $\mathrm{N}$ & - & - & - \\
\hline & $\begin{array}{l}\text { Flood and surge } \\
\text { defence }\end{array}$ & $\mathrm{Y}$ & $\begin{array}{l}\text { Protect the city from } \\
\text { flood and sea level } \\
\text { rise }\end{array}$ & $\begin{array}{l}\text { Dike and } \\
\text { (NCICD/ } \\
\text { seawall - } \\
\text { uncomplete) }\end{array}$ & $\begin{array}{l}\text { Coastline and } \\
\text { riverbank }\end{array}$ \\
\hline & $\begin{array}{l}\text { Micro level flood } \\
\text { protection }\end{array}$ & $\mathrm{N}$ & - & - & - \\
\hline & $\begin{array}{l}\text { Adaptation } \\
\text { measures }\end{array}$ & $\mathrm{Y}$ & Improve navigability & $\begin{array}{l}\text { Dredging, } \\
\text { proper waste } \\
\text { disposal }\end{array}$ & $\begin{array}{l}\text { River and } \\
\text { Whole city }\end{array}$ \\
\hline
\end{tabular}

Note: $\mathrm{Y}=$ Available; $\mathrm{N}=$ Not Available. Source: Adapted from Adnan and Kreibich (2016).

During his second presidential term, President Widodo announced a controversial policy to relocate the capital city to Kalimantan. The reason behind the relocation is to reduce Jakarta's overloaded problems including traffic congestion, air pollution, flood and land sinking. Another masterplan for new Indonesian capital city also received public attention and led to debate which deviates from the focus of this paper. In the next section, we will assess what has Jakarta done to address the issue of floods and sea level rise through the perspective of sea cities.

\section{Results and Discussions}

\subsection{Assessment of Jakarta's Strategies based on Sea Cities Perspective}

In addressing the challenge of floods and sea level rise, our assessment suggests that Jakarta does not yet have strategies related to storm surge natural barrier, building code/regulation, development control, protection of critical facilities, and micro-level flood protection, although most of them exist in other developed countries. Given all strategies that have generally been carried out in developed countries are adopted by Jakarta, our understanding on sea cities concept suggests that fortification tactic remains as the dominant strategy as presented in Table 4 (top row). This analysis corresponds to Garschagen et al (2018:1) study on flood risk reduction strategy in Jakarta, 'the focus is clearly on engineering solutions, foremost in the Giant Sea Wall project. The project is likely to transform the city's flood hydrology. However, it cements rather than transforms the current risk management paradigm which gravitates around the goal of controlling flood symptoms, rather than addressing their largely anthropogenic root causes.'

Presently, fortification tactic which involve both natural and structural approaches dominate Jakarta. However, Adnan and Kreibich (2016) state although Jakarta has concern with structural flood defence system, its protection standard remains to anticipate 10 years return 
period of flood, which is much lower than other cities such as Ho Chi Minh (50 years); New York, New Orleans and Melbourne (100 years); Copenhagen (200 years); Hongkong (900 years); London, Shanghai, Tokyo (1000 years) and Rotterdam (10000 years).

There are also uncertainties about the Indonesia's mega-infrastructure (e.g. NCICD) project (Van Dijk, 2016), related to the extremely expensive cost of project which overly relies on private sector financing. The project is also far too immense for a single developer or contractor to handle, thus it must be partitioned into several manageable projects, with no guarantee the parties involved in the project have the same amount of experience or skill available. Failure in one project component may lead failure to the other components. The success of infrastructure (e.g. NCICD) project also rely on other social readiness and change of community practice. For example, when the population continues to use ground water and dump sewer and waste in the already polluted rivers, expectation of giant freshwater retention will not materialize, instead there will be a big giant polluted rubbish and contaminated water retention. Therefore, intervention to change the habits of communities living along the thirteen rivers in Jakarta, towards being more environmentally friendly toward the rivers, also adds another layer of complexity towards the implementation of the project.

Energy dependence and the use of energy will be even greater following the adoption of fortification tactic. The NCICD masterplan design for example require upgrading and additional newer and bigger pumps to raise water from river deltas that are lower than sea level due to land subsidence towards retention ponds. Besides, operation and maintenance that is highly energy consumptive will be a burden that has not yet been fully calculated financially.

\section{Table 4. Assessment of Jakarta's Strategy Based on Sea Cities Perspective}

\begin{tabular}{|c|c|c|c|c|}
\hline & Fortify & Accommodate & Release & Floating \\
\hline & $\begin{array}{l}\text { Wetland protection; } \\
\text { Greening; Ecological } \\
\text { storm surge barrier*; } \\
\text { Micro level flood } \\
\text { protection*; Giant } \\
\text { sea wall (e.g. } \\
\text { NCICD Project) }\end{array}$ & $\begin{array}{l}\text { Risk zoning; } \\
\text { Building code*; } \\
\text { Development } \\
\text { control*; } \\
\text { Spontaneous } \\
\text { adaptation }\end{array}$ & $\begin{array}{l}\text { Relocation (to the } \\
\text { higher areas) } \\
\text { Moving the capital } \\
\text { city }^{*}\end{array}$ & \\
\hline Technical & \multirow[b]{2}{*}{$\begin{array}{l}\text { Rapid land- } \\
\text { subsidence hampers } \\
\text { out the tactic } \\
\text { (including ecological } \\
\text { barrier) as a long- } \\
\text { term solution, unless } \\
\text { adjustment is } \\
\text { constantly } \\
\text { performed. }\end{array}$} & \multirow[b]{2}{*}{$\begin{array}{l}\text { Land-subsidence } \\
\text { does not make this } \\
\text { tactic as a durable } \\
\text { solution. Adjustment } \\
\text { is required even in } \\
\text { shorter period ( }<10 \\
\text { years). }\end{array}$} & \multirow[b]{2}{*}{$\begin{array}{l}\text { There is no issue } \\
\text { with land } \\
\text { subsidence, but } \\
\text { Jakarta's hinterland } \\
\text { is already fully } \\
\text { occupied }\end{array}$} & \multirow[b]{2}{*}{$\begin{array}{l}\text { North Jakarta sea is } \\
\text { suitable for placing } \\
\text { large floating } \\
\text { structure (many } \\
\text { areas with less } 20 \\
\text { meters deep, } \\
\text { moderate level of } \\
\text { wave, and not in the } \\
\text { hurricane lane). }\end{array}$} \\
\hline $\begin{array}{l}\text { Geomorphologic } \\
\text { features }\end{array}$ & & & & \\
\hline Current zoning & $\begin{array}{l}\text { Zoning on Jakarta's } \\
\text { sea water is } \\
\text { required. } \\
\text { Major adjustment of } \\
\text { zoning is required } \\
\text { especially in the } \\
\text { reclaimed land/ } \\
\text { islands. }\end{array}$ & $\begin{array}{l}\text { Minor adjustment of } \\
\text { zoning is required in } \\
\text { the existing area. }\end{array}$ & $\begin{array}{l}\text { Major adjustment of } \\
\text { zoning may be } \\
\text { required in the } \\
\text { designated area. }\end{array}$ & $\begin{array}{l}\text { Minor adjustment of } \\
\text { zoning on Jakarta's } \\
\text { sea water is } \\
\text { required }\end{array}$ \\
\hline $\begin{array}{l}\text { Existing land } \\
\text { uses and } \\
\text { population } \\
\text { densities }\end{array}$ & $\begin{array}{l}\text { Several land uses } \\
\text { (e.g. fishermen } \\
\text { village, traditional } \\
\text { fish market and port) } \\
\text { are not taken into }\end{array}$ & $\begin{array}{l}\text { This tactic leads to } \\
\text { land use } \\
\text { consolidation which }\end{array}$ & $\begin{array}{l}\text { The density of } \\
\text { affected area is } \\
\text { extremely high. Lack } \\
\text { of vacant land to }\end{array}$ & $\begin{array}{l}\text { Jakarta's sea water } \\
\text { area is } 10.5 \text { times } \\
\text { larger than its land } \\
\text { territory. Total areas } \\
\text { submerged by }\end{array}$ \\
\hline
\end{tabular}




\begin{tabular}{|c|c|c|c|c|}
\hline & $\begin{array}{l}\text { account under this } \\
\text { tactic. }\end{array}$ & $\begin{array}{l}\text { is hardly achieved } \\
\text { in current context. }\end{array}$ & $\begin{array}{l}\text { implement this } \\
\text { tactic. }\end{array}$ & $\begin{array}{l}\text { ocean will increase } \\
\text { constantly. }\end{array}$ \\
\hline Environment & \multirow[b]{2}{*}{$\begin{array}{l}\text { The tactic produces } \\
\text { significant } \\
\text { environmental } \\
\text { destruction (in-situ } \\
\text { and ex-situ) due to } \\
\text { land reclamation. }\end{array}$} & \multirow{2}{*}{$\begin{array}{l}\text { Does not involve } \\
\text { land reclamation. } \\
\text { The existing habitat } \\
\text { is less affected. }\end{array}$} & \multirow[b]{2}{*}{$\begin{array}{l}\text { New (water) habitats } \\
\text { may emerge in the } \\
\text { existing abandoned } \\
\text { land. } \\
\text { Habitat invasion } \\
\text { may occur in new } \\
\text { designated lands for } \\
\text { relocation. }\end{array}$} & \multirow[b]{2}{*}{$\begin{array}{l}\text { Does not involve } \\
\text { land reclamation. } \\
\text { Impact on the } \\
\text { environment is } \\
\text { limited as the } \\
\text { system is designed } \\
\text { circularly. }\end{array}$} \\
\hline Existing habitats & & & & \\
\hline Culture & \multirow[b]{2}{*}{$\begin{array}{l}\text { Cultural attachment } \\
\text { and value are } \\
\text { maintained. } \\
\text { The success of this } \\
\text { tactic requires } \\
\text { drastic behaviour } \\
\text { change (e.g. in } \\
\text { groundwater use, } \\
\text { management of } \\
\text { solid waste). }\end{array}$} & \multirow{2}{*}{$\begin{array}{l}\text { Require minor } \\
\text { behaviour } \\
\text { adjustments (e.g. } \\
\text { daily activity) }\end{array}$} & \multirow[b]{2}{*}{$\begin{array}{l}\text { Does not change } \\
\text { much of the existing } \\
\text { culture. } \\
\text { Distance of travel to } \\
\text { existing coastal } \\
\text { based livelihoods } \\
\text { increase. } \\
\text { Community and } \\
\text { livelihoods are } \\
\text { detached. }\end{array}$} & \multirow[b]{2}{*}{$\begin{array}{l}\text { Communities do not } \\
\text { have cultural } \\
\text { attachment with } \\
\text { water. } \\
\text { How to bring land- } \\
\text { based culture to the } \\
\text { top of water is the } \\
\text { biggest challenge. }\end{array}$} \\
\hline $\begin{array}{l}\text { Cultural } \\
\text { attachment and } \\
\text { values }\end{array}$ & & & & \\
\hline Economy & \multirow[b]{2}{*}{$\begin{array}{l}\text { Increase in land } \\
\text { value, but } \\
\text { diminishing } \\
\text { livelihoods of } \\
\text { fishermen and } \\
\text { informal business } \\
\text { sectors. }\end{array}$} & \multirow[b]{2}{*}{$\begin{array}{l}\text { Slight increase in } \\
\text { land value if not } \\
\text { stable. } \\
\text { Some land-based } \\
\text { livelihoods diminish. }\end{array}$} & \multirow[b]{2}{*}{$\begin{array}{l}\text { Existing land area } \\
\text { will be abandoned } \\
\text { and annihilate the } \\
\text { market value. } \\
\text { Ocean will take over } \\
\text { the existing area. }\end{array}$} & \multirow[b]{2}{*}{$\begin{array}{l}\text { Existing land area } \\
\text { will be abandoned } \\
\text { and have no more } \\
\text { market value. } \\
\text { Ocean will take over } \\
\text { the area with new } \\
\text { market value. }\end{array}$} \\
\hline 'Takings' issues & & & & \\
\hline Cost & $\begin{array}{l}\text { Extremely expensive } \\
\text { to provide protective } \\
\text { infrastructure and } \\
\text { supporting } \\
\text { technology (e.g. 50B } \\
\text { USD for NCICD). } \\
\text { Long run } \\
\text { effectiveness is } \\
\text { questionable. Public } \\
\text { investment will be } \\
\text { continuously } \\
\text { required to adjust to } \\
\text { sea level rise } \\
\text { overtime and to } \\
\text { energy consumptive } \\
\text { operation. }\end{array}$ & $\begin{array}{l}\text { Less expensive. The } \\
\text { cost is justifiable for } \\
\text { government and } \\
\text { private parties. } \\
\text { For individual, the } \\
\text { cost is personal. The } \\
\text { total accumulation of } \\
\text { individual } \\
\text { investment may be } \\
\text { high. } \\
\text { Cost effectiveness is } \\
\text { unclear as } \\
\text { individual/ family } \\
\text { capacity differs. }\end{array}$ & $\begin{array}{l}\text { Relocation cost is } \\
\text { justifiable for } \\
\text { government, but it is } \\
\text { extremely expensive } \\
\text { especially for the } \\
\text { land provision. } \\
\text { For private and } \\
\text { individual parties, } \\
\text { relocation cost is } \\
\text { personal. } \\
\text { Cost effectiveness is } \\
\text { high for those who } \\
\text { are capable to afford } \\
\text { this strategy. }\end{array}$ & $\begin{array}{l}\text { Expensive for the } \\
\text { R\&D. } \\
\text { The cost is } \\
\text { justifiable for } \\
\text { government and } \\
\text { private parties. } \\
\text { For private and } \\
\text { individual parties, } \\
\text { the cost is personal. } \\
\text { Cost effectiveness is } \\
\text { high for private and } \\
\text { individual parties } \\
\text { who are capable to } \\
\text { afford this strategy. }\end{array}$ \\
\hline Politics & \multirow[b]{2}{*}{$\begin{array}{l}\text { Critic and resistance } \\
\text { arise when the } \\
\text { protective } \\
\text { infrastructure } \\
\text { prevents direct } \\
\text { access of fishermen } \\
\text { village from their } \\
\text { livelihoods. } \\
\text { There has been well } \\
\text { established } \\
\text { technology and } \\
\text { experience to } \\
\text { implement. Easier to } \\
\text { win popular support. }\end{array}$} & \multirow[b]{2}{*}{$\begin{array}{l}\text { Does not give } \\
\text { immediate political } \\
\text { advantages as the } \\
\text { impact of the tactic } \\
\text { remains small and is } \\
\text { relatively scattered. } \\
\text { Not easily detected } \\
\text { by voters. }\end{array}$} & \multirow[b]{2}{*}{$\begin{array}{l}\text { Relocation is a } \\
\text { political suicide in } \\
\text { Indonesian context. } \\
\text { Government will not } \\
\text { be able to afford this } \\
\text { tactic when the } \\
\text { people demands } \\
\text { compensation for } \\
\text { land in the existing } \\
\text { area. }\end{array}$} & \multirow[b]{2}{*}{$\begin{array}{l}\text { The tactic brings } \\
\text { political advantages } \\
\text { as it exhibit the } \\
\text { government's } \\
\text { seriousness in } \\
\text { dealing with the } \\
\text { ultimate solution that } \\
\text { looks ahead and } \\
\text { stimulates } \\
\text { advancement in } \\
\text { technology and } \\
\text { science. }\end{array}$} \\
\hline Political will & & & & \\
\hline $\begin{array}{l}\text { Political } \\
\text { boundaries or } \\
\text { jurisdictional } \\
\text { overlaps }\end{array}$ & $\begin{array}{l}\text { Involve jurisdictional } \\
\text { overlaps. }\end{array}$ & $\begin{array}{l}\text { Less issue with } \\
\text { jurisdictional } \\
\text { overlaps. }\end{array}$ & $\begin{array}{l}\text { Involve jurisdictional } \\
\text { overlaps. }\end{array}$ & $\begin{array}{l}\text { Involve jurisdictional } \\
\text { overlaps. }\end{array}$ \\
\hline
\end{tabular}

${ }^{*}=$ The strategy does not exist in Jakarta (see Adnan and Kreibich, 2016) or is not classified due to different scope and/or motivation 
Jakarta has some strategies that are classified as accommodating such as risk zoning and spontaneous adaptation efforts. While real adaptation measures in the city remain limited, risk zoning stop at the scoring and identification of vulnerable areas. Most of urban adaptations in Indonesia are not effective as they are partial, small-scale, short-term, mostly unplanned, autonomous and only at community level (Setiadi, 2018). For example, elevation of floors and houses are common adaptation strategies practiced by coastal communities in Indonesia, while government put materials and asphalts to elevate roads.

Jakarta has not used other strategies such as building codes and development control (e.g. through realignment of spatial planning) as part of accommodation tactic. Building codes are available for Jakarta, but they have not been adjusted according to the changing environmental conditions. The existing building code regulates the land coverage, building height, and basic design requirements for health, sanitation and rainwater infiltration. Unfortunately, the building code particularly do not regulate how to deal with fire, earthquake, flood and sea level rise. Even so, it is problematic to enforce existing building regulation, particularly to those in the bottom of the economic pyramid whose perception about living standard is different to normative planning regulation.

Spatial planning has potential as an instrument for controlling physical growth and development, which then can be used as part of accommodative tactic. However, Jakarta's current spatial plan cannot be categorized as part of accommodative tactic because it has not taken into account hydro-meteorological hazard, as many other Indonesian cities (Buchori et al, 2018). A study conducted by Suroso and Firman (2018) proves that the existing spatial planning of local government throughout the North Coastline of Java region, including Jakarta, is no longer reliable as an instrument to control development in responding to the future trends of sea level rise. In other words, there is no realignment idea in the north coast of Java, including Jakarta in the current spatial plan. Suroso and Firman (2018: 84) estimate that 'regional development capacity will decrease significantly in the future due to sea level rise in the North Coast of Java up to 2030 because 'a total area of 55,220 ha of land prone to inundation, including of protected area (1488 ha), fishponds (32,916 ha) and agricultural land (20,814 ha), is planned to be converted into industry $(13,399 \mathrm{ha})$ and settlements $(41,821 \mathrm{ha})$.... This change would potentially lead to an economic loss of 246.6 billion USD'.

At a glance, recent decision to move Indonesian capital, from Jakarta to Kalimantan seems as a part of release tactic. However, a further review on the government's idea contained in the official policy release (Bappenas, 2019; President Staff Office, 2019) and commentary (Salim and Negara, 2019) shows that the relocation of the capital is not for people affected by floods and sea level rise, it is only relocate government buildings, offices, and government-based activities. Relocation of the capital clearly will not save Jakarta from sea level rise.

Parallel to release, Jakarta has not implemented floating tactic and even has never engaged with the idea so far. In fact, Jakarta's sea area is approximately 10.5 times larger than its land area. This has not been considered by most urban planners. Wade (2019) criticize Indonesian planners which keep supporting on reclamation megaproject and underestimate other possibilities to address the sinking of Jakarta.

\subsection{Discussion}

Assumptions and planning concepts that only consider the past and short-term trends cannot produce resilient outcomes in face of regional environmental changes, such as the rising sea level. Sea city concept helps to develop a more comprehensive and long-term oriented way of thinking. However, it is not easy to answer which tactics will save Jakarta 
from flooding and future sea level rise since each tactic has its own strength and weakness. The most important at this stage is to realize what trajectory has Jakarta pursued and to raise more understanding on key factors for each tactic for Jakarta. Our assessment shows that fortify tactic, emphasising on either natural or infrastructural strategies would bring serious consequence in the future and it is not enough as the only tactic for Jakarta. Slobbe et al (2013) raised concern about the danger of reactive hard-infrastructure in dealing with sea level rises and storm-surge-induced floods in the long run caused by imbalance sediment transport, leading to the failure of the structure itself. Rapid land subsidence hampers out this tactic, which also includes provision of ecological barrier.

Release is likely the most unrealistic tactic technically, economically, and politically. Generally, there is no more space available to retreat within Jakarta. Relocation projects could fail due to irrational land price. When realignment occurs in the coastal areas, the capacity of government is likely limited to finance land acquisition in new place and pay compensation for the affected people.

Based on our proposed Sea Cities concept, we argue that the combination of accommodation and floating tactics have greater chances to address sea level rise challenges in Jakarta. While accommodation tactic is the most realistic option to address sea level rise in the transition period (i.e. one or two decades), floating tactic offers a longterm prospect.

Geomorphologically, most Indonesian water, including Jakarta coast, is very suitable for implementing floating strategy. Jakarta coast, which has many areas with 20 meters deep, relatively stable waves and not located in the hurricane lane, presents basic technical criteria for development floating structure. The floating tactic is more environmentally friendly because it does not involve reclamation activities. These tactics open opportunities for Jakarta to end its path dependency and develop new future pathways in dealing with sea level rise. It could open opportunity in advancing science and technology and preparing social transition for its people. In an optimistic way, it can stimulate new scientific, technological and social innovation.

Floating is indeed prospective for solving problems in the long run, but there are also some obstacles that must be considered to ensure its effectiveness for Jakarta. The fundamental question in adaptation to climate change is how we can find effective but affordable strategies (Setiadi, 2018). Are floating structures and its supporting facilities able to host at least 1.6 million people in Jakarta who are affected by sea level rise by 2050 ? Are these structures affordable? In other words, economic feasibility of floating tactic is also important aspect to consider. This tactic is unordinary and might be less preferred by pragmatic politicians who only secure popular votes. Contrarians may argue that the cost to build structure on top of water is expensive, but the cost of environmental degradation and sustainability resulted from the fortification tactic (e.g. giant seawall) should not be excluded from the calculation. An objection to this pessimistic view about floating cities is with the case of development on land could be more expensive. For example, the cost of development of 40,000 hectares of new Indonesian capital in Kalimantan to host 1.5 million residents is estimated at 34 billion USD (Bappenas, 2019). It does not calculate the land clearing of natural forest in the designated area. Another example, an experiment to build eco-friendly, zero waste and carbon of 40,000 residents in only two square miles or nearly equal to 580 hectares of land in the city of Masdar in Dubai is also expensive with a cost of 18 billion USD (Frith, 2017).

In order to understand what transitions needed for Jakarta to take up non-fortification tactics, Slobbe et al (2013) underline that the state of a coastal management options is basically the result of interactions between three basic elements: hydro-morphological and ecological 
processes (nature), the engineering system (agents' interventions through technology advancement), and societal system (formal and informal institutions). Though the physical and natural conditions are suitable, and the technology is available, societal system is the most challenging part to deal with. Is the combination of accommodating and floating tactics really the aspiration of communities to deal with the impact of climate change, particularly sea level rise? Some experts (e.g. Marengo et al, 2017) suggest co-development of adaptation strategies to deal with future consequences of sea level rise, which emphasises deliberative process involving stakeholders.

Torabi, et al (2018) suggest that agents who are involved in urban developments are key holders as they are able to influence institutions and urban physical systems. Local planners, politicians, communities, governments, and developers need be educated and informed about the importance of developing cities on top of water that are environmentally friendly, and at the same time is a long-term solution in responding to sea level rise. Currently there is vast knowledge on predictive coastal vulnerability and sea level rise modelling available to decision-makers. Yet there remains a significant gap between this scientific information and the implementation of local coastal adaptation policies and planning. The concept of sea cities needs to be considered in responding to operationalize this gap. From a legal base, marine spatial zoning needs to be made, so that it does not conflict with the use of existing seas such as shipping lines, fish catching, underwater cables, marine aquaculture, etc.

Delaying the debate about the need for solutions beyond coastal protective infrastructure will cause even more complex problems in the future. Debate must start now before it is too late. The main debate should be about the ability of Jakarta to survive by taking a fortification based infrastructural trajectory as carried out by Rotterdam, or should Jakarta approach the issue with a higher order level of thinking to deal with sea level rise. Albert Einstein's quotes 'the significant problems we have created cannot be solved at the same level of thinking that created them', need to be considered.

\section{Conclusion}

This study concludes that approach that is oriented towards massive hard-structural solutions is not only insufficient, but also irrelevant to solve Jakarta's problems in facing the challenges of climate change, especially rising sea level. It will be a dilemma for themselves and are contested because of their ecological impacts, the inclusiveness issue of the affected community, and its long-term effectiveness. A more integrative and interdisciplinary approach is needed, viewing the sea as potential space that needs to be considered in extending urban development in Jakarta. Sea cities concept is very useful to diagnose this problem. Our analysis shows that the combination of accommodating and floating tactics have never been considered as a possible solution to sea level rise in Jakarta. The combination of these two tactics needs to be considered for the future development trajectory of Jakarta. Sea cities can be a new framework for development of coastal cities. The concept of sea cities operates the notion that sea is a part of our future.

\section{Acknowledgments}

The principal author(s) acknowledge generous support and sabbatical grant provided by Diponegoro University, Indonesia through World Class University Program under agreement number: 1023/UN7.P/HK/2019. The principal author also thanks to Cities Research Institute, Griffith University Australia for being a remarkable and stimulating host during the writing process. 


\section{References}

Adnan, S.G., \& Kreibich, H. (2016). An evaluation of disaster risk reduction (DRR) approaches for coastal delta cities: a comparative analysis. Natural Hazards, 83, 1257-1278. doi: 10.1007/s11069016-2388-8

Ali, M., Rasimin, R., Ilyas, I., \& Muttaqin, Z. (2019). Communication of environmental awareness: the paserong for sustainable development of the orang bajo. ICEASD, April 01-02. DOI: 10.4108/eai.1-42019.2287179

Apip, A., Sagala, S., \& Pingping, L. (2015). Overview of Jakarta water- related environmental challenges. Water and Urban Initiative Working Paper Series 4, UNU-IAS.

Bappenas, 2019. Plan for the shifting of the national capital. Policy Brief. Jakarta.

Barragán, J.M., \& Andrés, M. (2015). Analysis and trends of the world's coastal cities and agglomerations, Ocean \& Coastal Management, 114, 11-20. doi:

http://dx.doi.org/10.1016/j.ocecoaman.2015.06.004

Booth, R. (2008, April 26). Pitfalls in paradise: why Palm Jumeirah is struggling to live up to the hype. The Guardian.

Bruyns, G., \& Hasdell, P. (2017). Aquatic urbanity: water as planning and territorial instrument considering the 9 dash line policy. Journal of Urban Planning, Landscape \& environmental Design, 2(3), 273-284

Bryant-Tokalau, J. (2018). Adaptation to climate change in the Pacific Islands: theory, dreams, practice and reality. In: Bryant-Tokalau, J. (Ed) Indigenous Pacific approaches to climate change (pp. 33-57), Cham: Palgrave Pivot. doi: https://doi.org/10.1007/978-3-319-78399-4 3

Buchori, I., Sugiri, A., Mussadun, M., Wadley, D., Liu, Y., Pramitasari, A., \& Pamungkas, I. (2018). A predictive model to assess spatial planning in addressing hydro-meteorological hazards: a case study of Semarang City, Indonesia. International Journal of Disaster Risk Reduction, 27, 415-426. doi: https://doi.org/10.1016/j.ijdrr.2017.11.003

Buckman, S., \& Hamdan, A. (2016). Add water and they will come? demographic assessment of place-based canal-oriented development. Journal of Urban Regeneration and Renewal, 9(4), 353366.

Bus, P., Treyer, L., \& Tartar, A. (2018). Customised floating neighbourhoods: design interfaces for non-experts and designers to explore emergent floating formations in: W. Huang., M. Williams., D. Luo., Y. Wu., \& Y. Lin. (Eds.) Learning, prototyping and adapting, Proceedings of the 23rd International Conference on Computer-Aided Architectural Design Research in Asia (CAADRIA), Hong Kong.

Clark, N.M. (2016). Florida's future: new modes of development for our coastal communities, in: N.M. Clark (Ed.) Urban waterways: evolving paradigms for hydro-based urbanism (pp. 47-58). Florida: LADC UNESCO and University of Florida.

Clemente, M. (2013). Sea and the city: maritime identity for urban sustainable regeneration. Territorio della Ricerca su Insedianment e Ambiente TRIA, 6(2), 19-34. doi: 10.6092/2281-4574/2095

CRI (2009). SeaCities: Exploring the next frontier of human settlement. Griffith University. https://www.seacities.org/principles 
Dahlem, J. (2019). Analysis of ocean-space and sea-level rise policy in two coastal cities. Coastal Management, 47(3), 312-336. doi: 10.1080/08920753.2019.1596679

Delphine, D., Busquet, M., Santpoort, R., Witte, P., \& Spit, T. (2019). Living on the edge: Identifying challenges of port expansion for local communities in developing countries, the case of Jakarta, Indonesia. Ocean and Coastal Management, 171, 119-130. https://doi.org/10.1016/j.ocecoaman.2019.01.021

Deltares. (2015). Sinking cities: an integrated approach towards solutions. Delft/ Utrecht, The Netherlands. Retrieved from https://www.deltares.nl/app/uploads/2015/09/Sinking-cities.pdf

Frith, C. (2017). Breaking the horizon. Bachelor of Architecture Theses. Kennesaw State University.

Fu, X., Gomaa, M., Deng, Y., \& Peng, Z. (2017). Adaptation planning for sea level rise: a study of US coastal cities. Journal of Environmental Planning and Management, 60(2), 249-265. doi:

10.1080/09640568.2016.1151771

Garschagen, M., Surtiari, G.A.K., \& Harb, M. (2018). Is Jakarta's new flood risk reduction strategy transformational? Sustainability, 10, 2934. doi:10.3390/su10082934

Gibbs, M.T. (2019). Consistency in coastal climate adaption planning in Australia and the importance of understanding local political barriers to implementation. Ocean and Coastal Management, 173, 131-138. doi: https://doi.org/10.1016/j.ocecoaman.2019.03.006

Hanson, S., Nicholls, R., Ranger, N., Hallegatte, S., Corfee-Morlot, J., Herweijer, C., \& Chateau, J. (2011). A global ranking of port cities with high exposure to climate extremes. Climatic Change, 104, 89-111. doi: 10.1007/s10584-010-9977-4

Hill, K. (2016). Climate change: implications for the assumptions, goals and methods of urban environmental planning. Urban Planning, 1(4), 103-113. doi: 10.17645/up.v1i4.771

Hurlimann, A., Barnett. J., Fincher, R., Osbaldiston, N., Mortreux, C., \& Graham, S. (2014). Urban planning and sustainable adaptation to sea-level rise. Landscape and Urban Planning, 126, 84-93. doi: http://dx.doi.org/10.1016/j.landurbplan.2013.12.013

IPCC. (2013). 'Sea level change' in: The Fifth Assessment Report of the Intergovernmental Panel on Climate Change. pp.1137-1216.

Jakarta Post. (2019, July 2). Jakarta's giant sea wall enter the next phase with help Dutch, Korean Partner.

Marengo, J.A., et al.(2017). A globally deployable strategy for co-development of adaptation preferences to sea-level rise: the public participation case of Santos, Brazil. Natural Hazards, 88, 3953. doi: 10.1007/s11069-017-2855-x

Mariano, C., Marino, M. (2018). Water landscapes: from risk management to an urban regeneration strategy. Journal of Urban Planning, Landscape \& Environmental Design, 3(1), 55-74.

Matsumoto, T. (1985). An analysis of off-shore man-made island. Ocean Space Utilization, 85, 7-14.

Mega, V.P. (2019). Eco-responsible cities and the global ocean: geostrategic shifts and the sustainability trilemma. Springer. doi: https://doi.org/10.1007/978-3-319-93680-2

Neumann, B., Vafeidis, A.T., Zimmermann, J., \& Nicholls, R.J. (2015). Future coastal population growth and exposure to sea-level rise and coastal flooding: a global assessment. PLOS ONE, 10(3), e0118571. doi: 10.1371/journal.pone.0118571 
Nicholls, R.J. (2011). Planning for the impacts of sea level rise. Oceanography, 24(2), 144-157. url: https://www.jstor.org/stable/10.2307/24861275

Octavianti, T., \& Charles, K. (2018) Disaster capitalism? examining the politicisation of land subsidence crisis in pushing Jakarta's seawall megaproject. Water Alternatives, 11(2), 394-420.

President Staff Office (2019) The shifting of government centre: analysis and perspective from defence and security. Policy Brief, 26 June. Jakarta.

Pultrone, G. (2014). Trieste and its port as paradigm of a renewed sea-oriented vision?. Territorio della Ricerca su Insediamneti e Ambiente TRIA ,12(1),103-120. doi: 10.6092/2281-4574/2071

Reiblich, J., Wedding, L.M., \& Hartge, E.H. (2017). Enabling and limiting conditions of coastal adaptation: local governments, land uses, and legal challenges. Ocean and Coastal Law Journal, 22, 156-194.

Reise, K. (2017). Facing the third dimension in coastal flatlands: global sea level rise and the need for coastal transformations. GAIA, 2, 89-93. doi: https://doi.org/10.14512/gaia.26.2.6

Salahuddin, B. (2006). The marine environmental impacts of artificial island construction Dubai, UAE. Masters Project. The Nicholas School of the Environment and Earth Sciences of Duke University.

Salim, W., \& Negara, S.D. (2019). Shifting the capital from Jakarta: reasons and challenges.

Perspective 2. ISEAS. Singapore. url:

https://iseas.edu.sg/images/pdf/ISEAS_Perspective_2019_79.pdf

Samant, S., \& Brears, R. (2017). Urban waterfront revivals of the future. In: P.Y. Tan., \& C.Y. Jim (Eds.) Greening cities, forms and functions: advances in 21st century human settlements. Springer Nature, Singapore. doi: 10.1007/978-981-10-4113-6_15

Save Jakarta Bay Coalition (2006) Joint letter of concern on the government of the Netherlands support on reclamation of 17 artificial islands and NCICD project in Jakarta Bay. Retrieved from https://www.tni.org/en/article/national-capital-integrated-coastal-development-ncicd-project-in-jakartabay

Setiadi, R. (2018). A roadmap to effective urban climate change adaptation. Earth and Environmental Science IOP Conference Series, 129. url: http://iopscience.iop.org/article/10.1088/1755$1315 / 129 / 1 / 012041$.

Shannon, E. (2018) Resilient architecture: adaptive community living in coastal locations. Master Theses. 665. The University of Massachusetts Amherst. Retrieved from https://scholarworks.umass.edu/masters_theses_2/665

Slobbe, E.V., De Vriend, H.J., Aarninkhof, S., Lulofs, K., De Vries, M., \& Dircke, P. (2013). Building with nature: in search of resilient storm surge protection strategies. Natural Hazards. 65, 947-966. doi: 10.1007/s11069-012-0342-y

Suroso, D.S.A., \& Firman, T. (2017). The role of spatial planning in reducing exposure towards impacts of global sea level rise case study: Northern coast of Java, Indonesia. Ocean and Coastal Management, 153, 84-97. doi: https://doi.org/10.1016/j.ocecoaman.2017.12.007

Torabi, E., Dedekorkut-Howes, A., \& Howes, M. (2018). Adapting or maladapting: building resilience to climate-related disasters in coastal cities. Cities, 72, 295-309. doi: http://dx.doi.org/10.1016/j.cities.2017.09.008

UN-DESA. (2019). World Urbanization Prospect 2018 Revision. New York: United Nations. 
UN-SDG. (2019). Sustainable Development Goals 14. Retrieved from https://sustainabledevelopment.un.org/sdg14

Van Dijk, M.P. (2016). Financing the national capital integrated coastal development (NCICD) project in Jakarta (Indonesia) with the private sector. Journal of Coastal Zone Management, 19(5), 435. doi: 10.4172/2473-3350.1000435

Vrees, L.D. (2019). Adaptive marine spatial planning in the Netherlands sector of the North Sea. Marine Policy, https://doi.org/10.1016/j.marpol.2019.01.007

Wade, M. (2019). Hyper-planning Jakarta: the great garuda and planning the global spectacle. Singapore Journal of Tropical Geography, 40, 158-172. doi: 10.1111/sjtg.12262

Wang, G., Goldfeld, Y., \& Drimer, N. (2019) Expanding coastal cities: proof of feasibility for modular floating structures (MFS). Journal of Cleaner Production, 222, 520-538. doi: https://doi.org/10.1016/j.jclepro.2019.03.007

Ward, P.J., Marfai, M.A., Yulianto, F., Hizbaron, D.R., \& Aerts, J.C.J.H. (2011). Coastal inundation and damage exposure estimation: a case study for Jakarta. Natural Hazards, 56, 899-916. doi: $10.1007 / \mathrm{s} 11069-010-9599-1$

Ware, D. (2017). Sustainable resolution of conflicts over coastal values: a case study of the Gold Coast Surf Management Plan. Australian Journal of Maritime \& Ocean Affairs, 9(2), 68-80. doi: 10.1080/18366503.2017.1278501 